\title{
3. The internal and external centralisation of Capital Markets Union regulatory structures: the case of Central Counterparties
}

\author{
Fabio Bulfone and Agnieszka Smoleńska
}

\subsection{INTRODUCTION}

The aim of this chapter is to study if, how and to what extent the recent reforms of the regulatory framework for central counterparty clearing houses (CCPs) have led to a centralisation of the supervisory authority over the EU financial sector. The reform of the CCP regulation, known as the European Market Infrastructure Regulation (EMIR) was part of the Capital Markets Union (CMU) project. The CMU is a package of regulatory reforms unveiled in 2015 as one of the flagship projects of the Juncker Commission. It has the ambitious goal of deepening, integrating and diversifying the EU financial market, focusing in particular on non-banking segments like bond issuance, corporate bond securitisation, public equity investment, venture capital and credit intermediation by specialised non-bank financial firms (i.e. leasing companies and consumer finance companies) (Quaglia et al. 2016). Implementation of the various CMU proposals has indeed led to a reshaping of the regulatory framework for many financial activities, marking a landmark moment in EU financial regulation. At the same time, this regulatory activity has been contentious, as it has required strengthened cross-border intra-EU and extra-EU regulatory and supervisory cooperation. This is particularly true for the regulation of CCPs, which - as market infrastructure - are a key node of internal market integration, making them an ideal vantage point from which to study regulatory and supervisory centralisation in a horizontal and vertical perspective (Smoleńska 2017). In doing so, we will assess the plausibility of four hypotheses presented in the introduction to this volume, those dealing with regulatory outcomes depending on the compatibility of EU Member States' regulatory structures and international agreements (hypothesis 3), the Commission's power of initiative as a driver of centralisation (hypothesis 5), regulatory competition 
between financial powers (hypothesis 6) and the impact of regulatory arbitrage on supervisory and regulatory centralisation (hypothesis 7).

CCPs are financial market infrastructure tasked with reducing risk in financial transactions by interposing themselves between the two counterparties in a derivative contract (i.e. acting as buyer to the seller and seller to the buyer). They have recently come to occupy a pivotal position in financial markets as a consequence of the commitment made by G20 leaders in 2009 at the Pittsburgh Summit that over-the-counter (OTC) derivatives should be centrally cleared to increase transparency and reduce systemic risk. Prior to the G20 statement calling for their direct supervision, CCPs were not regulated, being treated as private insurances used by the parties in a transaction. The G20 commitment was transposed into EU legislation in 2012 with the EMIR regulation - one of the first post-crisis reforms of the EU financial regulatory framework. EMIR granted a number of competences in the regulation of CCPs to the European Securities Markets Agency (ESMA), one of the three European Supervisory Authorities (ESAs) established in 2010. Since then, the size of EU-based CCPs has grown. Between 2009 and 2015 the share of OTC interest-rate derivatives centrally cleared jumped from 36 to 60 per cent (Busch 2018, pp. 35-6). Centrally cleared interest rate swaps (IRS) witnessed even more impressive growth, going from 23.3 to 88.5 per cent of the total between 2007 and 2017 (Genito 2019, p. 939). As of 31 December 2017, the notional amount of outstanding OTC derivatives was more than EUR 500 trillion worldwide, of which interest rate derivatives represented more than 75 per cent and foreign exchange derivatives almost 20 per cent.

CCP operations are also contentious from a regulatory and supervisory perspective because of their extreme degree of geographical concentration. For example, in 2018 the UK housed three CCPs responsible for the clearing of 75 per cent of euro-denominated interest rate swaps, the largest category of OTC derivatives (House of Lords 2018), which is seen as problematic by the central bank of issuance, namely the ECB. Given the dramatic increase in transaction volume and their market infrastructure function, large UK-based CCPs like LCH Clearnet are perceived as having become 'too big to fail' as an insolvency of one of them would risk plunging the EU financial sector into crisis (Friedrich and Thiemann 2017). Consequently, while central clearing of OTC derivatives may indeed improve market resilience, the cross-border scope of their activity coupled with their uneven geographical distribution (i.e. concentration in London) makes CCPs a potential source of systemic risk (Genito 2019). This will be even more so when Brexit takes place as a large share of euro-denominated transactions will be located outside the formal jurisdiction of euro-area supervisors and of the central bank that issues the currency in which the bulk of transactions are made, that is, the ECB. This issue had already sparked controversy before the Brexit referendum, with the ECB 
unsuccessfully seeking to force the relocation of transactions in euros within its jurisdiction as early as 2010 under the ill-fated Location Policy (Marjosola 2015). While the EU courts have denied the ECB the competence to regulate CCPs and therefore to impose a forced relocation of euro-denominated clearing, the role of the issuing central bank in regulating CCPs has become the focal point of the EMIR review process. The outcome of the Brexit referendum in 2016 further contributed to creating a sense of urgency, as the withdrawal of the UK from the common regulatory framework increases the risk of supervisory loopholes. This dynamic, coupled with the persistently low level of investment in the EU, motivated the Commission to table a number of measures aimed at centralising supervision of CCPs as part of the CMU initiative.

In this chapter, we provide a legal analysis of the regulatory structure for CCPs put in place by the 2019 EMIR reform (EMIR 2019) coupled with a political science analysis of the factors which led to this regulatory outcome. As we detail below, the new rules give rise to a complex regime which differentiates between CCPs active in the EU market established in one of the EU Member States (intra-EU CCPs) and those that provide cross-border services in the EU but are based in third countries (extra-EU CCPs). While ESMA has acquired considerable direct supervisory powers over the extra-EU CCPs operating in the EU market (i.e. third-country CCPs such as those established in Hong Kong, Singapore and the US), national authorities retain supervisory powers over intra-EU CCPs (i.e. CCPs established in one of the EU Member States, such as LSH SA in France and Eurex Clearing in Germany). In other words, supervision has become more centralised for extra-EU than intra-EU CCPs. This differentiated regime has emerged despite the fact that in its initial proposal the Commission, flanked by the ECB, had called for the establishment of a single supervisory framework for intra-EU and extra-EU CCPs.

The remainder of the chapter is organised as follows. Section 3.2 locates our contribution within the framework developed in the volume's theoretical chapter, and in particular within the vertical international and horizontal international perspectives. Section 3.3 provides a detailed legal analysis of the EMIR framework as agreed by the European Parliament and the Council in spring 2019 (EMIR 2019). Particular attention is devoted to discussion of the emergence of a differentiated supervisory structure for EU-based and extra-EU CCPs. It will be shown that, while ESMA acquired direct supervisory powers over extra-EU CCPs, the supervision of intra-EU CCPs remains decentralised at Member State level. As far as the applicable rules are concerned, they are uniform and centralised for all CCPs (both intra- and extra-EU), given that EMIR is directly applicable across the EU and supplemented by ESMA technical standards. Section 3.4 details the political dynamics leading to this differentiated supervisory outcome. It highlights that both supervisory centralisation over extra-EU CCPs and the lack of centralisation over EU-based 
CCPs result from a dual dynamic involving a state-centred 'neo-mercantilist' battle (Howarth and Quaglia 2018, p. 1118) between different financial centres to attract financial investment outflowing from London in the context of Brexit and the bureaucratic competition between different EU authorities to strengthen their supervisory powers. Finally, section 3.5 concludes by providing reflections on and refinements of the hypotheses presented in the theoretical chapter.

\subsection{RELEVANT HYPOTHESES, OPERATIONALISATION OF CONCEPTS AND RELEVANT ACTORS}

In line with this volume's theoretical chapter, centralisation of regulatory structures is defined as an uploading of decision-making competences to the EU level via a strengthening of the existing powers or a broadening of the mandate of ESMA and/or the ECB vis-à-vis national competent authorities (NCAs). Instead, we define decentralisation as a process in which extensive powers are given to or retained by the NCAs of Member States. Fragmentation is defined as a situation in which unforeseen dynamics lead to a sub-optimal regulatory framework characterised by loopholes or supervisory conflicts.

We study regulatory structure outcomes bearing in mind that financial regulation is characterised by a high level of heterogeneity arising from the interaction between different regimes in place for different financial activities, such as banking and trading in financial instruments, and different supervisory cultures at the national level. Furthermore, to identify the structure it is necessary to consider its different components, that is, market access rules (the authorisation required), supervision (obtaining information, investigative powers and enforcement) and the oversight of equivalence regimes (specific powers to grant market access to third-country entities). In the EU, regulatory structures may be established on the basis of generally applicable regulations (MiFIR, EMIR) or may require transposition at the national level when they result from directives (AIFMD, UCITS). Finally, as is discussed in Chapter 4 of this volume, EU regulation may centralise regulatory structures by establishing a common framework of rules and yet leave their implementation (i.e. supervision) decentralised. In the following sections we will evaluate the impact of the 2019 EMIR regime, primarily focusing on the centralisation of the regulatory structure for supervision, given that full rule-centralisation already occurs under the generally applicable EU regulation.

The CCP market has two defining features - its important cross-border dimension and its geographical concentration in the UK - that make it a particularly interesting case to study two of the research perspectives presented 
in the theoretical framework: the vertical international and the horizontal international perspectives.

In line with the vertical international perspective, the regulation of CCPs at the EU level came about in response to international pressure for regulatory harmonisation stemming from the G20 Pittsburgh statement calling for mandatory clearing of derivatives traded through central counterparties and oversight of them. This commitment was subsequently transposed into EU law following a legislative proposal by the European Commission. Coherently with the vertical international perspective, this top-down pressure then had a differentiated impact on the Member States. One explanation for this is the heterogeneity of domestic regulatory, and also economic, structures. Furthermore, the process of implementing global commitments sparked different reactions from authorities at the EU level. The concomitant effect of these different dynamics led to a differentiated regulatory outcome with a co-existence of elements of centralisation, decentralisation and fragmentation. In the vertical international perspective, our legal and political analysis of EMIR 2019 helps us refine two hypotheses, which we discuss in the final section of this chapter:

Hypothesis 3. If centralised regulatory structures proposed by the EU are compatible with those in large powerful Member States, centralisation is more likely.

Hypothesis 5. Under the conditions required by international agreements, in the absence of powerful veto players the Commission will be able to increase its institutional power in financial regulation, which equals a centralisation of regulatory structure.

However, the Brexit referendum has made the CCP case perhaps even more relevant from the point of view of the second research perspective, which focuses on horizontal international competition between states and regional polities hosting large financial centres. In fact, as a result of the Brexit process, the UK will go from being home to the largest financial sector - and CCP market - in the EU to becoming an external (but highly integrated) financial powerhouse. We will show that the uncertainty surrounding this scenario has had a profound impact on the content of EMIR 2019. This allows us to assess the plausibility of two hypotheses:

Hypothesis 6. Regulatory competition between leading financial powers prompts regulatory centralisation in other actors' internal regulatory structures. 
Hypothesis 7. A high degree of transnational regulatory arbitrage by financial firms will lead to more coordination between two public regulatory actors if one of the parties takes a leading role in such coordination. This in turn exerts pressure for more regulatory centralisation within each regional polity.

To assess the plausibility of these hypotheses, we focus on the preferences of some of the pivotal actors in the EU legislative process with due regard to the way in which they have been reshaped by the Brexit shock. These are: the European Commission, the European Parliament, the European Central Bank and the largest EU Member States - France and Germany. The European Commission has the exclusive right of legislative initiative, which it uses to set the agenda for legal reforms and to propose the content of future legislation. In the areas of integration considered, legislation is passed under the ordinary legislative procedure, that is, the European Parliament and a qualified majority of Member States in the Council must agree on the new rules. Within the Council, we focus on the preferences of France and Germany, as they are pivotal owing to the size of their economies and the weight of their votes within the Council. Furthermore, Paris and Berlin are two important EU financial centres housing the largest CCPs on the continent in terms of the notional value of daily OTC transactions (ESMA 2019b, p. 41). We therefore assume that no major regulatory reform of the EU financial framework for CCPs can be approved without their support. The relative weight of France and Germany has further increased as a result of the Brexit referendum, as the EU is losing what was arguably its most influential member on financial regulation matters (Moloney 2017). Over the course of the Great Financial Crisis, the European Parliament acquired important expertise in financial matters, which has enabled it to exert greater influence over the content of financial regulation in EU legislative processes. This activism came in response to growing concerns about financial regulation among EU voters. Although the preferences of the European Parliament are naturally as heterogeneous as those of its members, we assume that, due to the scope of their mandate, MEPs will focus on the institutional dimension of regulations. Hence, they will be particularly sensitive to the distribution of regulatory responsibilities among institutions and to issues of accountability. Finally, to the extent that the ECB has direct legislative competences with regard to the regulation of economic and financial matters in the $\mathrm{EU}$, and as during the eurozone crisis it emerged as the most decisive EU institution, we consider expressed ECB preferences to be an important variable determining the distribution of powers within the regulatory structures. In particular, the ECB was active in the 2019 EMIR reform to the extent that its competences with regard to oversight of CCPs were affected, including via an amendment to its statute. For the most part, however, the ECB was a rule-taker in the processes we discuss. 
We argue that supervisory centralisation can only come about when it matches the preferences of all these pivotal actors. This is also true when decisions are taken under qualified majority voting, as in the case of the EMIR, because notwithstanding voting rules the EU Council strives for consensus (in fact the voting results show that all the EMIR amendments were unanimously adopted by all the Member States). Until the Brexit referendum, the UK's resistance within the Council prevented supervisory centralisation for both intra-EU and extra-EU CCPs. The referendum and the consequent withdrawal of the UK from actively shaping EU regulations in the Council removed a veto player on supervisory centralisation. However, while the UK's departure catalysed sufficient support for the centralisation of supervision over extra-EU CCPs, Germany and other Member States in the Council opposed the centralisation of supervision over intra-EU CCPs, thereby leading to a decentralised outcome.

This chapter relies on a thorough analysis of EU legal rules, secondary sources, press releases, newspaper articles and official documents from the European Commission, the European Central Bank, the European Parliament, and the French, German and UK governments. This material is supplemented with interviews with three policymakers, namely a key financial adviser to the Juncker Commission (Interview 1), a policy advisor in the European Parliament (Interview 2) and an expert from the EU Council services (Interview 3).

\subsection{CCP REGULATORY STRUCTURES UNDER THE EMIR FRAMEWORK}

The EMIR 2019 reform put in place a complex regulatory structure with different regimes for CCPs established in the EU (intra-EU CCPs) and for those which provide services in the EU market but are established in third countries (extra-EU CCPs). In this section, we provide a detailed analysis of this two-pronged regulatory structure (see Table 3.1).

The first common EU regulatory framework for CCPs (EMIR) was established in 2012, making the oversight of CCP activities a matter of generally applicable EU regulation. The package was originally approved in July 2012 and came into force a month later (EMIR 2012). The EMIR 2012 regulation introduced mandatory clearing of OTC derivative transactions via CCPs. It defined a CCP as a "legal person that interposes itself between the counterparties to the contracts traded on one or more financial markets, becoming the buyer to every seller and the seller to every buyer" (Smoleńska 2017, p. 141). EMIR regulated the operation of and access to CCPs and introduced rules for access to the EU market by CCPs established in third countries.

EMIR introduced common rules for market entry for CCPs, that is, the conditions which such financial institutions need to fulfil to meet the requirements 
for authorisation. These included specific rules such as the level of capital requirements and governance standards. To allow for such a centralising effect, the legislative instrument chosen was a regulation. Furthermore, EMIR was adopted on the basis of Art. 114 TFEU, which grants the EU a general competence for regulating the internal market, rather than the service-specific Art. 53(1) TFEU, which was used in the case of MIFID (see Chapter 4 of this volume). The use of this legal basis allowed the regulation to have more far-reaching centralising effects, including granting specific supervisory competences to EU bodies.

Despite this centralisation of rules, however, supervision remained substantially decentralised, as national competent authorities retained responsibility for the application of the centralised regulatory requirements with regard to intra-EU CCPs. In terms of the locus of supervision, EMIR did not prescribe whether the domestic supervisor should be an independent agency or the central bank, which led to the emergence of heterogeneous supervisory architectures across the Member States. In half of the Member States, including France, domestic CCPs are supervised by the central bank, while in nine (including Germany, Austria and Poland) supervision rests with the designated financial market authority. With regard to extra-EU CCPs, EMIR established a general equivalence regime which allowed market access to third-country CCPs if their home supervision met the requirements established in EU rules. Under the equivalence regime, ESMA was responsible for 'recognising' third-country CCPs operating on EU territory on the basis of a decision adopted by the European Commission (Arts. 13 and 25 EMIR). In other words, extra-EU CCPs would formally continue to be supervised by their respective home authorities, with the role of ESMA confined to verifying that the conditions for continued recognition of the rules governing their behaviour, such as risk management, were "functionally equivalent" to EU rules. Specifically, ESMA had the competence to assess whether there was a cooperation agreement in place with the relevant supervisory authority, whether the CCP was authorised in the third country and in full compliance with the rules, whether the Commission adopted an equivalence decision and whether there was a risk of money-laundering related to the activity (since 2015). The 2012 EMIR foresaw no direct role for ESMA in the oversight of EU CCPs. The EU agency's role was therefore limited to collecting information about any new CCP authorisations and mediating when different national authorities disagreed over matters relating to the supervision of CCPs operating cross-border. Therefore, although EMIR brought some form of harmonisation, overall the regulatory structure remained decentralised for intra-EU CCPs and fragmented for third-country CCPs (with their activity not being fully captured by the regulatory structure). 
The 2019 reform of EMIR strengthens supervisory centralisation, although in a differentiated manner. The regime for EU-based CCPs will continue to be decentralised with a key role for the relevant domestic supervisor. However, some partial elements of centralisation are introduced, such as the granting of a strengthened supervisory role for cross-border colleges (networks of supervisors) and an enhanced regulatory power for ESMA (the 'internal dimension' of the regulatory structure). Instead, centralisation replaces the fragmented regime for extra-EU CCPs in the 'external dimension' (see Table 3.1). Specifically, ESMA has acquired direct supervisory competences for the authorisation, supervision and enforcement of regulations with regard to central counterparties providing services in the EU market. The following sections outline these two distinct regulatory outcomes in more detail.

\subsubsection{The Internal Dimension: The Supervision of EU-based CCPs}

Following the 2019 EMIR reform, the regulatory structure for intra-EU CCPs will remain primarily decentralised with regard to the implementation of the rules, that is, national authorities will continue to supervise the CCPs established in the EU. However, despite the maintenance of a decentralised structure, the 2019 EMIR reform introduces a number of marginal centralising features. Under the new rules, CCPs established in one of the Member States will continue to be supervised by the domestic authority on the basis of authorisations. Such authorisations are then valid across the entire EU territory (Art.10(5), 14 and Art. 22 EMIR; ESMA 2019). However, the reform complicates the regulatory structure by, to some extent, strengthening the supranational dimension: first, by enhancing the role of the CCP supervisory colleges which were established under the 2012 EMIR regime, bringing together the various authorities in the jurisdictions where a CCP operates; second, by assigning ESMA new residual competences; and third, by specifying the role of central banks in CCP supervision as opposed to financial supervisors, thus intervening more intrusively in the decentralised structure. We explain these marginal features of centralisation below.

First, under the new regulatory regime the (centralised) supranational colleges gain more powers. While under the previous regime colleges were only to be consulted regarding the authorisation and ongoing supervision of intra-EU CCPs (i.e. they had no powers), under the 2019 EMIR if the competent authority deviates from the college's opinion it must explain why (Art. 19(4) EMIR, as amended). Thus, via the centralised colleges, various new authorities gain influence over the ongoing supervision of CCPs, including: (a) ESMA; (b) the competent authorities responsible for the supervision of large clearing members of the CCP; (c) the competent authorities responsible for the supervision of trading venues served by the CCP; (d) competent authorities 
supervising CCPs with which interoperability arrangements have been established; (e) competent authorities supervising central securities depositories to which the CCP is linked; (f) the relevant members of the ESCB responsible for the oversight of the CCP and the relevant members of the ESCB responsible for the oversight of CCPs with which interoperability arrangements have been established; and (g) the central banks issuing the most relevant EU currencies in which the cleared financial instruments are denominated. The inclusion of central banks within the colleges reflects awareness by the legislator of the impact CCP activities might have on monetary financial stability. The rules governing the operation of colleges are centralised and published by ESMA (ESMA 2019a).

Second, with the 2019 EMIR reform ESMA acquires some competences vis-à-vis the ongoing intra-EU CCP supervision. Specifically, a new dedicated CCP Supervisory Committee is established within ESMA, which brings together the national competent authorities but also includes full-time independent members of the Supervisory Committee appointed by members of ESMA's Board of Supervisors, subject to approval by the European Parliament. The CCP Supervisory Committee can assist national supervisors in the exercise of their tasks, such as the drafting of relevant supervisory decisions. EMIR thus allows for 'opt-in' centralisation of authority. While as a rule the role of ESMA with regard to supervision of intra EU-CCPs remains advisory, if the relevant national authority asks it to, the ESMA CCP Supervisory Committee can act as a de facto supervisor. Such 'opt-in' centralisation of supervision is allowed so national authorities may benefit from ESMA's resources or (centralised) expertise.

Third, the decentralised nature of the supervisory framework for intra-EU CCPs is qualified by the fact that, unlike EMIR 2012, EMIR 2019 regulates the institutional regulatory structure, delimiting the functions of the national central bank and the independent supervisor in crisis scenarios. A specific role is now foreseen for issuing central banks in crisis situations, meaning that although supervision remains decentralised in normal times in periods of instability - at least for euro area countries - the ECB will have a specific role in implementing crisis measures. The ECB has argued, however, that such a regulatory structure is fragmented as there is no harmonised role for the issuing central banks in ongoing supervision. Over the course of the legislative process the ECB has indeed argued that it should be endowed with a non-exhaustive list of measures and tools, and it was encouraged to do so by the CJEU judgment in the Location Policy case (Marjosola 2015; Draghi 2018).

Following the 2019 EMIR reform the regime for intra-EU CCP supervision remains formally decentralised, as the primary responsibility for decision-making and enforcement remains with the domestic regulators of each Member State. However, this decentralisation is qualified by: (a) parallel 
centralisation under cross-border supervision colleges; (b) opt-in centralisation through the CCP Supervisory Committee of ESMA; and (c) centralisation of the role of central banks in crises.

\section{Table 3.1 The EU regulatory structure for CCPs after the 2019 reform}

\begin{tabular}{llll}
\hline & Centralised & Decentralised & Fragmented \\
\hline Intra-EU & substantive rules (EU regulation) & supervision & $\begin{array}{l}\text { ongoing supervision by } \\
\text { central banks }\end{array}$ \\
CCPs & $\begin{array}{l}\text { supervisory colleges } \\
\text { opt-in centralisation (ESMA) }\end{array}$ & \\
& crisis role of central banks & & \\
Extra-EU & determination of the systemic nature & oversight of \\
CCPs & of third country Tier 1 CCPs & non-systemic \\
& supervision of Tier 2 CCPs & (Tier 1) \\
\hline
\end{tabular}

\subsubsection{The External Dimension: The Supervision of Extra-EU CCPs}

EMIR 2019 creates a centralised supervisory structure for extra-EU CCPs operating in the EU. Specifically, the reform establishes a two-tier regime for third-country CCPs operating in the EU, with new supervisory powers being centralised in ESMA, and in particular in the newly-established CCP Supervisory Committee mentioned above. Under the 2012 EMIR regime, ESMA's powers of supervision over extra-EU CCPs operating in the EU territory were limited to monitoring the alignment of supervisory standards. After 2019 , the regulatory and supervisory regime for extra-EU CCPs will be more centralised than that for intra-EU CCPs, as ESMA has been granted powers of direct supervision differentiating between different types of CCPs depending on their systemic importance in the EU market.

First, EMIR 2019 centralises in ESMA the competence for the determination of the systemic nature of CCPs. The conditions for determining this systemic relevance are established by EU regulations and include: the nature, size and complexity of the CCP; the potential effect a disruption to the CCP's activities would have on financial markets; the structure of the CCP's clearing membership, including access to information in this regard; the substitutability of the services provided by the CCP; and the CCP's interconnectedness with other EU financial structures (Art. 25(2a) EMIR). CCPs deemed non-systemic by ESMA (Tier $1 \mathrm{CCPs}$ ) continue to be supervised by third-country authorities as under the pre-reform regime. However, ESMA is assigned the competence to directly supervise 'systemically important' CCPs (Tier 2 CCPs). ESMA-supervised Tier 2 CCPs are also subject to stricter supervisory rules 
covering a wide array of issues, including margin requirements, liquidity risk control, collateral, settlement and the approval of interoperability arrangements under EMIR. Therefore, the new extra-EU CCP regulatory structure endows ESMA with a Kompetenz-Kompetenz, that is, the ability to determine - on the basis of specific criteria - whether or not it is the direct supervisor of a given extra-EU CCP operating in the internal market.

Second, the 2019 reform centralises supervision over extra-EU CCPs by endowing the newly-established Supervisory Committee with the same powers national authorities have over intra-EU CCPs. In addition to the general powers relating to fines and investigation, ESMA will now enjoy a special power to withdraw recognition with regard to the important (Tier 2) extra-EU CCPs, which would then require such entities to establish (relocate) in one of the EU Member States. Hence, under certain circumstances, Tier 2 CCPs might be obliged to relocate to a Member State and submit to the direct supervision of a national authority should they wish to continue to provide their services in the EU. We therefore observe a full centralisation of decision-making powers by ESMA vis-à-vis systemically important third-country CCPs.

A related example of centralisation of regulatory structure over extra-EU CCPs, which is nevertheless unlikely to be implemented, is included in the 'no-deal' Brexit planning foreseen by the European Commission in the case of a disorderly withdrawal of the UK from the EU. Contingency plans foresaw a centralised framework for the oversight of UK CCPs which, following the execution of Brexit, would immediately become third-country financial institutions from the perspective of the other EU Member States. The special EU regulations put in place foresaw that EU authorities would be granted special and unprecedented powers under the emergency rules which would govern financial transactions between the EU and the UK in the event of a no-deal Brexit. The dedicated Commission Delegated Regulation grants special monitoring powers to ESMA over systemically important CCPs (European Commission 2018).

To sum up, EMIR 2019 has created a differentiated CCP regulatory structure in the EU. Different rules apply to intra-EU CCPs and extra-EU CCPs. With regard to intra-EU CCPs, the supervisory structure remains decentralised despite a limited strengthening of the role of ESMA and of the cross-border supervisory colleges, together with some regulation of the oversight function of central banks. With regard to extra-EU CCPs, a centralised framework is established for CCPs considered systemically important in the internal market. Below, we assess the extent to which this regulatory outcome can be explained by (a) compatibility between centralised structures and the regulatory structures of the large Member States; (b) the European Commission's entrepreneurial behaviour in transposing an international agreement; and (c) regulatory competition between financial centres in the post-Brexit-referendum scenario. 


\subsection{THE POLITICAL DIMENSION: EXPLAINING THE EMERGENCE OF A DIFFERENTIATED SUPERVISORY REGIME}

In 2015, the Commission launched a 'regulatory fitness' check of the EMIR legislation. The REFIT public consultation led the Commission to conclude that within the industry there was broad support for the EMIR regime, and that the existing regulatory framework only needed minor adjustments. Following some of the comments emerging from the consultation, in 2017 the Commission launched a legislative proposal, EMIR 'Refit', to streamline clearing and reporting obligations. The initiative was welcomed both by the CCP industry and the UK Treasury (House of Lords 2017).

However, the UK's decision to notify its intention to withdraw from the EU as a consequence of the June 2016 referendum led the Commission to change its approach to the regulation of CCPs. The possibility of having the largest providers to the EU financial sector of clearing services located outside the EU motivated a legislative proposal calling for a centralisation of the supervisory framework for both extra-EU CCPs and intra-EU CCPs in June 2017. The European Commission's communications accompanying the legislative proposal explicitly linked the prospect of Brexit with the need to centralise supervision over CCPs (Arriba-Sellier 2019). For instance, in a 2017 communication to the EP, the Parliament and the Council, the Commission stated that:

\footnotetext{
... the foreseen withdrawal of the United Kingdom from the EU will have a significant impact on the regulation and supervision of clearing in Europe. At present, as much as $75 \%$ of euro-denominated interest rate derivatives are cleared in the UK. Derivatives denominated in some other Member States' currencies are also cleared in the UK. These transactions directly impact the responsibilities, including in the area of monetary policy, of the relevant EU and Member State institutions and authorities ... specific arrangements based on objective criteria will become necessary to ensure that, where CCPs play a key systemic role for EU financial markets and directly impact the responsibilities, including financial stability and monetary policy, of EU and Member State institutions and authorities, they are subject to safeguards provided by the EU legal framework. This includes, where necessary, enhanced supervision at EU level and/or location requirements. (European Commission 2017a)
}

Despite the fact that above all Brexit affects the regulation and supervision of extra-EU CCPs (i.e. London's CCPs will transform from intra-EU CCPs to extra-EU CPPs if they continue to provide services in the internal market), in its initial legislative proposal the Commission called for the establishment of a centralised supervisory regulatory structure for both intra-EU and extra-EU CCPs. The fact that the regime which emerged in the end creates a differentiated regime leads us to analyse the negotiations and regulatory outcomes 
concerning the internal and external dimensions of supervisory centralisation separately in the following sections.

\subsubsection{Explaining the Regime for Intra-EU CCPs: National Resistance to Supervisory Centralisation}

The Commission's initial legislative proposal involved a centralisation of the supervision of intra-EU CCPs combining an extension of ESMA's supervisory powers with an expansion of the powers of the 'Central Bank of Issuance' (CBI). The CBI is the bank issuing the currency in which cleared transactions are denominated, that is, the ECB in the case of euro-denominated transactions (European Commission 2017b). The Commission explicitly linked the push for supervisory centralisation to a need to avoid regulatory arbitrage within the EU:

First, the growing concentration of clearing services in a limited number of CCPs, and the consequential increase in cross-border activity, implies that CCPs in a small number of individual Member States are increasingly relevant for the EU financial system as a whole. Against this trend, the current supervisory arrangements relying mainly on the home-country authority ... need to be reconsidered. Second, diverging supervisory practices for CCPs ... across the EU can create risks of regulatory and supervisory arbitrage for CCPs and indirectly for their clearing members or clients.

Brexit made this threat of intra-EU regulatory arbitrage even more plausible as large financial centres like Paris, Frankfurt and Dublin entered into direct competition to attract financial investment outflows from London. Due to its geographical distribution (i.e. concentration in the UK), clearing is a particularly delicate market segment in this regard, as the Commission explicitly acknowledged:

The departure of the United Kingdom from the Single Market reinforces the urgent need to further strengthen and integrate the EU capital market framework, including on central counterparties (CCPs), investment firms and markets for initial public offerings (IPOs). It also strengthens the need for further integration of supervision at EU level. (European Commission 2017c)

One should note that within our theoretical framework an enhancement of the supervisory powers of the central bank would equate to supervisory centralisation for the eurozone countries - even if the overall structure of independent supervisors remains decentralised - since EMU Member States share a common 'bank of issuance'. In the Commission's initial proposal, however, we find that two alternative projects for supervisory centralisation developed, one giving power to ESMA and the other to the central banks (i.e. the ECB for eurozone-based CCPs). The European Commission's original proposal leaning 
towards strengthening the role of central banks was accompanied by an ECB proposal to amend its statute to allow for such enhanced supervisory powers (Arriba-Sellier 2019, p. 713). Arguing that disturbances in the functioning of CCPs might impede the ability of the ECB to fulfil its mandate to maintain price stability, the ECB proposed being given direct supervisory powers over both intra-EU and extra-EU CCPs in the case in which the latter cleared significant amounts of euro-dominated transactions (European Central Bank 2017). The initiative was coordinated with the EMIR reform proposal put forward by the European Commission (Smoleńska 2017; Arriba-Sellier 2019). The UK reacted to the ECB's proposal with suspicion, seeing it as an attempt to revive Frankfurt's ambition to impose a relocation to the eurozone of UK-based CCPs clearing euro-denominated OTCs (House of Lords 2017).

Despite the Commission's strong push for supervisory centralisation, however, in the final agreement on the new EMIR legislation reached in 2019, the provisions leading to a strengthening of ESMA and the ECB's supervisory powers were considerably watered down (Interview 1). With regard to intra-EU CCPs, while all central banks (and therefore also the ECB) are granted some additional supervisory powers, as discussed above, these only apply to crisis situations. ESMA, meanwhile, gained limited supervisory powers and only at the request of national supervisors. The supervision of EU-based CCPs therefore remains essentially decentralised at the Member State level. We argue that two factors concurred in motivating this decentralised outcome. First, strong resistance emerged within the Council from Germany and other Member States to the uploading of supervisory authority to the EU level. Second, the European Parliament opposed strengthening the ECB's supervisory powers (Arriba-Sellier 2019; Interview 2).

Within the Council, Germany took a leading position in opposing the broadening of ESMA's supervisory powers over intra-EU CCPs in an effort to protect the prerogatives of domestic regulators. Other Member States, including Austria, Spain and Sweden, backed the German position (Reuters 2017; James and Quaglia 2019). During the negotiations, the German government even suggested formally splitting the draft legislation in two and discussing supervision of intra-EU and extra-EU CCPs separately (Brunsden and Stafford 2017). This came as little surprise as German authorities have always been somewhat reluctant to see supervisory and regulatory powers over domestic entities uploaded (see, for instance, Deutsche Bundesbank 2014; German Federal Government 2014; Moloney 2017). Already in 2011 during the negotiations on the first EMIR package, Germany presented a joint amendment with the UK stating that national competent authorities, and not EU agencies, should retain the power to authorise and supervise CCPs operating in their domestic markets (Financial Times 2011a). This view was also shared by 
the Deutsche Börse Group, owner of the German CCP European Commodity Clearing (ECC). According to Deutsche Börse:

CCPs already today have established a supervisory college including all relevant European supervisory authorities. This well-functioning college structure, with well-established relationships and well-experienced NCAs, should be continued and not changed to direct supervision by ESMA. (Deutsche Börse Group 2017, p. 3)

Apart from this general concern about uploading supervisory and regulatory powers over domestic financial entities to the EU level, the German opposition to centralisation should be seen in the context of the competition to attract financial firms relocating from London after Brexit. In fact, over the course of Brexit negotiations (2016-2019), national supervisory authorities of countries hosting large financial centres, like Germany, France, Luxembourg and Ireland, engaged in a process of regulatory fine-tuning aimed at making their domestic markets more attractive to prospective foreign investors (Howarth and Quaglia 2018; Grossule 2019). This dynamic created strong incentives for regulatory and supervisory leniency, with a regulatory race to the bottom within the EU potentially ensuing (Friedrich and Thiemann 2017; Arriba-Sellier 2019). Of course, the implementation of this 'neo-mercantilist' strategy is conditional on the retention of ample supervisory powers by national supervisors. This in turn explains the strong resistance to supervisory centralisation over intra-EU CCPs coming from Germany. Even though France and the Netherlands were more supportive of a strengthening of ESMA's supervisory powers (Interview 1), vetoes by Germany and other Member States within the Council prevented the emergence of a consensus, therefore leading to a decentralised outcome.

The EU legislators also watered down the proposal to grant enhanced supervisory powers over CCPs to central banks (such as the ECB). In the agreement reached between the Council and the European Parliament, the scope of central bank supervisory powers was restricted to CCPs located in third countries and crisis scenarios, and even then with serious limitations (Arriba-Sellier 2019). The European Parliament also resisted the ECB's push for more supervisory powers for reasons related to the accountability of the supervisor (Interview 2). In fact, the European Parliament secured for itself considerable powers over the process of selection and oversight of the members of ESMA's CCP Supervisory Committee, powers that it does not have over the ECB. For this reason, the EP was more positive about strengthening the CCP Supervisory Committee than that of the ECB.

Disappointed with the marginal extension of its supervisory powers, the ECB withdrew its initial proposal for an amendment of its statute, blaming the failure on Member State reluctance to shift supervisory authority over EU-based CCPs away from national regulators (Brunsden and Jones 2019). 
In a harshly-worded letter to the Council, the ECB complained that under the new framework it would not enjoy sufficient supervisory powers over CCPs established within the EU and would therefore lack power over a considerable amount of euro-dominated transactions (European Central Bank 2019).

\subsubsection{Explaining the Regime for Extra-EU CCPs: The Role of the Commission as Policy Entrepreneur and the Neo-Mercantilist Competition Between Financial Centres after Brexit}

The Brexit referendum, and the consequent spectre of the departure of a substantial part of the CCP industry from the EU, turned the regulation of extra-EU CCPs into a hotly-debated negotiating issue. In its initial proposal, the Commission planned to give ample regulatory powers over extra-EU clearing houses to ESMA and the relevant CBI. The proposal also envisaged a possibility for ESMA and the CBI to force the relocation of systematically important extra-EU CCPs (the so-called 'Tier 2') if they cleared a considerable amount of transactions in an EU currency. This proposal amounted to "a significant centralisation of financial supervision in critical areas" (Arriba-Sellier 2019, p. 709). The European Commission referred to Brexit and the ensuing risk of regulatory arbitrage as the main driver of the reformist initiative:

\footnotetext{
there is a risk that changes to the CCP rules and/or regulatory framework in a third country could negatively affect regulatory or supervisory outcomes, leading to an un-level playing field between EU and extra-EU CCPs and creating scope for regulatory or supervisory arbitrage ... Moreover, a substantial volume of euro-denominated derivatives transactions (and other transactions subject to the EU clearing obligation) is currently cleared in CCPs located in the United Kingdom. When the United Kingdom exits the EU, there will therefore be a distinct shift in the proportion of such transactions being cleared in CCPs outside the EU's jurisdiction, exacerbating the concerns outlined above. This implies significant challenges for safeguarding financial stability in the EU that need to be addressed. (European Commission 2017d)
}

The UK was understandably very critical of the proposal, particularly the aspects of it related to a forced relocation of CCPs. Summarising the position of the cabinet, the UK Economic Secretary argued that "The Government does not support the inclusion of location requirements for substantially significant third-country CCPs in the proposal. A location policy is inconsistent with [a global approach to CCP regulation] and would risk fragmenting global derivatives markets" (House of Lords 2017).

However, after the Brexit referendum the UK de facto lost its veto power over financial regulation negotiations and in the final stages withdrew from the EMIR negotiations altogether. This is in stark contrast with the cases of 
earlier post-crisis reforms like Solvency II, AIFMD, EMIR 2012 and MIFID II, over which the UK had succeeded in exerting a decisive influence, leveraging its unparalleled regulatory expertise (for a detailed analysis, see City of London 2016). For instance, in the case of EMIR 2012 the negotiating effort by the UK Chancellor George Osborne prevented both the centralisation of supervision for intra-EU CCPs and the adoption of a regulatory design penalising UK-based CCPs vis-à-vis their eurozone counterparts (Financial Times 2011b). The UK was not alone in criticising the relocation policy requirement. Negative opinions on the forced relocation of euro-denominated derivatives also came from the US-based International Swaps and Derivatives Association (ISDA) and from FIA (FIA 2017; ISDA 2017).

Compared to the case of intra-EU CCPs, the decisive driver of supervisory centralisation was the fact that in the case of extra-EU CCPs both France and Germany supported a strengthening of ESMA's mandate. This support should again be seen in the context of the 'neo-mercantilist' competition between EU financial centres to attract firms relocating from London (Quaglia and Howarth 2018, p. 1118). France's position stemmed from a hope that the imposition of strict regulatory requirements would push UK-based CCPs to relocate in the EU. Already in 2009, a confidential document addressed to the Minister of Finance, Christine Lagarde, mentioned euro-denominated clearing as a strategically important segment for the euro area and for France, advising the government to ask for a forced relocation of these activities to the eurozone (James and Quaglia 2019, pp. 7-8). In June 2016, a few days after the Brexit referendum, the French President, François Hollande, explicitly called for a relocation of euro-denominated clearing to the EU (Financial Times 2016). For his part, the head of Banque de France suggested that $\mathrm{LCH}$, the clearing house controlled by the London Stock Exchange, should develop interest rate clearing services in Paris (Financial Times 2018b). While Germany initially did not have a strong preference on the issue of CCP regulation, since 2016 and amid pressure from Deutsche Börse, the government started pleading for a forced relocation of euro-denominated clearing (Batsaikhan et al. 2017; James and Quaglia 2019). For instance, the Minister of Finance, Olaf Scholz, argued that "To minimise risk for financial stability, it is indispensable that [the central clearing of euro-derivatives clearing] is subject to strong regulation and supervision in full conformity with EU standards" (Financial Times 2018a). The French and German financial lobby groups Paris Europlace and Frankfurt Finance were also at the forefront of this effort to attract financial investment from London to increase competitiveness.

The joint support by the Commission, the European Parliament, France and Germany allowed ESMA to acquire considerable supervisory powers over extra-EU CCPs under the new EMIR regulation (Arriba-Sellier 2019). However, the system became more complex since ESMA was awarded more 
supervisory leverage over extra-EU CCPs than over intra-EU CCPs. Instead, an intervention by the Council and the European Parliament led to a mitigation of the initial proposal concerning the forced relocation of extra-EU CCPs, a move welcomed by both the UK authorities and UK-based CCPs (UK HM Treasury 2018).

Hence, while the removal of the UK as a veto player explains the enhanced supervisory centralisation over extra-EU CCPs, the lack of support within the Council for supervisory centralisation of intra-EU CCPs explains the decentralised outcome. These shifting preferences within the Council should in turn be seen in the context of the 'neo-mercantilist' 'battle' among different financial centres within the EU to attract financial firms relocating from London (Howarth and Quaglia 2018). The changing attitude of the German government is particularly telling in this regard. While, on the one hand, Germany favoured the establishment of a centralised supervisory framework for UK-based CCPs as this would lead them to relocate within the EU, on the other hand, by retaining ample supervisory powers over domestic CCPs Germany could still tailor its regulatory framework to the demands of prospective financial investors.

\subsection{DISCUSSION OF HYPOTHESES AND CONCLUSION}

In this chapter we have shown how the emergence of a differentiated supervisory framework for intra-EU and extra-EU CCPs in the context of the 2019 reform of EMIR can be explained by looking at the preferences of five decisive actors: the European Commission, the European Parliament, the ECB, France and Germany. We have argued that two interrelated factors were decisive in leading to the differentiated supervisory framework emerging as a result of the EMIR 2019 reform: an alignment of preferences between France and Germany generated by a 'neo-mercantilist' dynamic of competition to attract financial investment from the UK (Quaglia and Howarth 2018, p. 1118); and the Brexit referendum. First, even if the EMIR did not require unanimity, centralisation would only have been possible if it was compatible with the preferences of France, Germany and the European Parliament. While such preference alignment came about in the case of extra-EU CCPs, in the case of EU-based CCPs, resistance by Germany and other Member States within the Council prevented supervisory centralisation. As a result, the supervisory framework for intra-EU CCPs remains decentralised at the domestic level, with centralised EU agencies only playing an auxiliary role in supervision. Second, the Brexit process and the consequent prospect of a departure of the largest provider of CCP services to the EU acted as a regulatory shock with a profound impact on the CCP regulatory framework. However, it allowed for a greater alignment 
of preferences with regard to the centralisation of supervision of extra-EU CCPs. In this final section, we evaluate the level of supervisory and regulatory centralisation achieved from the point of view of two of the perspectives presented in the theoretical chapter: the horizontal international and the vertical international perspectives.

\subsubsection{CCP Regulation and the Vertical International Perspective}

The EU regulatory structure for CCPs was first established in response to a joint agreement reached at the G20 level in Pittsburgh in 2009. Coherently with the vertical international perspective, this common international pressure played out differently at the EU level and at the domestic level of each Member State. In this regard, our analysis is particularly relevant to assessing the plausibility of hypotheses 3 and 5 .

Our findings are relevant to hypothesis 3 in that we find that the preferences of large Member States had a decisive impact on regulatory and supervisory outcomes. However, unlike in $H 3$, we do not find compatibility with the formal domestic regulatory structures of Member States to be the decisive factor in the formation of such preferences. In fact, if hypothesis 3 were accurate we would expect large Member States to support the designing of supranational regulatory institutions matching their domestic regulatory frameworks. In the case of $\mathrm{CCP}$ regulation and supervision there is a great deal of heterogeneity between Member States in terms of their domestic structures. In some Member States CCPs are regulated by the central bank, in others by domestic financial regulators and yet in others there is a more dispersed supervisory system with both the financial regulators and the central bank sharing competences. Looking in more detail at the domestic regulatory structures of France and Germany, we see that the former has a diffused supervisory framework in which the Banque de France shares competences with two regulators (Autorite des Marchés Financiers and Autorité de Contrôle Prudentiel), whereas in Germany the domestic market watchdog BaFIN has the core of the competences, with a more marginal role for the Bundesbank. If hypothesis 3 were to apply to our case we would expect Germany to strongly support an uploading of supervisory authority over EU-based CCPs to ESMA, as this would closely match its domestic supervisory architecture. Instead, we would expect the French position to be more ambiguous. However, the preferences of both countries do not seem to align with these expectations. In fact, Germany strongly opposed supervisory centralisation for intra-EU CCPs in the EU-level supervisor, while France was more positive about a centralised solution, specifically including strengthening the role of the central bank. Concerning the supervision of extra-EU CCPs, the positions of these two countries seem to match hypothesis 3 more closely. In fact, both countries supported a centralised framework with 
a strengthening of ESMA that was compatible with their domestic regulatory frameworks, as it would not require any modification of the existing supervisory structures. However, our analysis has also allowed us to highlight that Member States' preferences are not solely influenced by the formal design of their domestic regulatory structures. Instead, other factors related to their domestic economies, like the desire to foster the competitiveness of their financial sectors, seem to play a more decisive role in shaping Member States' preferences. In fact, France and Germany also supported the centralisation of the supervisory framework for extra-EU CCPs within ESMA in the hope that the creation of a centralised supervisory framework for UK-based CCPs would lead them to relocate part of their activity in the EU, with Paris and Frankfurt set to profit from this dynamic.

Our findings also refine hypothesis 5, which posits that the Commission might exploit international agreements to increase its own institutional role in financial regulation, thereby leading to centralisation. To the extent that ESMA is an EU agency exercising power delegated by the European Commission and over which the latter exercises oversight, a strengthening of ESMA equates to a strengthening of the Commission. In line with the argument developed in the introduction to this volume, we have found that the Commission was able to strategically use its power of legislative initiative to propose measures leading to supervisory centralisation. This happened in the cases of both the 2012 EMIR and the 2019 EMIR reform. In the case of the 2012 EMIR, which we have briefly touched upon in this chapter, the Commission seized the opportunity created by the international agreement reached by the G20 on the clearing of OTC derivatives to table a legislative proposal giving the newly-established ESMA supervisory powers over CCPs. Even though the proposal did not then succeed in gaining support from the European Parliament and the Council, the swift legislative initiative by the Commission was nevertheless a decisive driver of regulatory centralisation. In the case of the 2019 EMIR reform too, the Commission seized the opportunity created by another exogenous event - the decision by the UK government to withdraw from the EU - to launch another legislative proposal to centralise the supervisory structures for both intra-EU and extra-EU CCPs. Again, even though centralisation was resisted by the EU Council, the legislative initiative allowed the European Commission to pursue supervisory centralisation in the context of Brexit, allowing for a profound reform of the supervisory regime for extra-EU CCPs.

However, the Commission was not the only EU institution playing a decisive role in shaping financial regulation and neither did it only pursue centralisation in areas which it formally controls. In fact, in our case study covering the internal dimension of supervisory centralisation we have shown how bureaucratic competition might ensue between different EU institutions seeking to gain supervisory powers over specific market segments (James and Quaglia 2019). 
In the case of EMIR, two alternative projects did emerge, one giving supervisory powers to the ECB and the other to ESMA. In the end, quite puzzlingly, the newly-created ESMA ended up acquiring more supervisory powers than the all-powerful ECB. The European Parliament played a decisive role in determining this outcome, as it supported strengthening ESMA rather than the ECB (on the role of the European Parliament, also see Chapter 2 of this volume). This preference can be explained by the fact that under EU law the Parliament can exercise greater oversight over ESMA (an EU body) than over the ECB (an independent and institutionally insulated EU institution). Such powers of oversight include specific accountability arrangements relating to appointments and to the institutional budgets. In fact, although the regime for intra-EU CCPs would prima facie appear to be decentralised (formal powers remain with the national competent authority), as a result of bureaucratic competition and diverging views regarding accountability within the regulatory structure, we have identified a diffused regulatory structure which combines elements of decentralisation (formal powers) with centralisation (expertise, auxiliary advice). We argue that intra-EU agency competition is decisive in explaining this fragmented outcome (Busuioc 2016). This allows for a refinement of hypothesis 5, which suggests that the European Commission is the primary EU-level policy entrepreneur supporting centralisation, as it would lead to its institutional empowerment. Instead, we have shown that multiple EU agencies might engage in this process, supporting alternative models of centralisation. Furthermore, we have found the European Commission to be the only EU institution with a general preference for centralisation, even if it does not directly lead to an enhancement of its own powers.

\subsubsection{CCP Regulation and the Horizontal International Perspective}

The fact that the CCP industry is heavily concentrated in the UK makes the study of its post-Brexit regulation particularly relevant for the horizontal international perspective, which focuses on the impact that competition with other global financial centres has on EU regulatory structures. In fact, by potentially turning the largest financial centre in Europe from a member of the EU into an extra-EU financial centre, the Brexit referendum could increase the horizontal competition between the EU and the UK.

The uncertainties related to the Brexit process provide a particularly interesting assessment of hypothesis 6 , which argues that growing regulatory competition between financial powers prompts regulatory centralisation in other actors' internal regulatory structures. We find this claim to be disconfirmed by our empirical analysis. In fact, once the Brexit process is brought to completion, the UK will become a (regulatory) financial power in direct competition with the EU, even if its CCPs may remain an essential component of the EU 
financial infrastructure. Following hypothesis 6 , the close interconnection between the two financial centres would create strong incentives for the centralisation of supervisory and regulatory structures within the EU. However, our analysis of the internal dimension of supervisory centralisation shows an opposite outcome, which can be explained as follows. Despite the fact that the Commission, the Parliament and the ECB all supported the establishment of a centralised regulatory and supervisory framework for EU-based CCPs, explicitly citing the threat of growing regulatory competition from the UK as a reason for this centralisation, resistance by Member States within the Council prevented the establishment of a centralised framework. This resistance is in turn explained by the desire to attract financial investment outflows from the UK. Where we observe centralisation, however, is with regard to the CCPs which provide services in the EU market but which are established in third countries (like the UK CCPs, which will become extra-EU once the Brexit process is brought to completion).

This latter observation allows us to assess the plausibility of hypothesis 7, according to which a high degree of transnational regulatory arbitrage by financial firms will lead to more coordination of supervisory and regulatory structures in order to reduce the scope for arbitrage. We find that the regulatory preferences of the Commission align with this hypothesis. In fact, the Commission justified its legislative initiative to centralise the supervisory framework for both intra-EU and extra-EU CCPs on the ground that Brexit increases the scope for regulatory and supervisory arbitrage, and therefore called for the establishment of a more centralised framework. However, reducing regulatory and supervisory arbitrage did not seem to be a concern for Member States within the Council, at least in the case of intra-EU CCPs. Instead, Member States supported a decentralised supervisory framework for two reasons: first, to protect the prerogatives of domestic regulators; and second, in the hope that this might help them tailor domestic supervisory standards on the needs of potential investors. Rather than reducing the scope for regulatory arbitrage, this 'neo-mercantilist' strategy is further increasing it, potentially leading to a race to the bottom between EU countries in terms of supervisory standards. On the other hand, the centralisation of supervision over extra-EU CCPs confirms hypothesis 7, as growing concern with regulatory arbitrage between the EU and the UK led to the establishment of a centralised structure with regard to third-country CCPs providing services in the EU market. 


\section{NOTE}

1. By 'neo-mercantilism' we mean any activist effort by governments or other state actors to favour the international competitiveness of domestic sectors or firms deemed strategic.

\section{BIBLIOGRAPHY}

Arriba-Sellier, N.D. (2019), 'The Brexit reform of European financial supervision: lost in transition?' European Business Law Review, 30 (4), 695-719.

Batsaikhan, U., R. Kalcik and D. Schoenmaker (2017), 'Brexit and the European financial system: mapping markets, players and jobs,' Bruegel Policy Contribution.

Brunsden, J. and Jones, C. (2019), 'ECB attacks EU plans for boosting supervision of clearing houses,' Financial Times. Accessed 4 January 2020 at: https://www.ft.com/ content/74ddbdb0-4735-11e9-a965-23d669740bfb.

Brunsden, J. and Stafford, P. (2017), 'EU clearing plans for City run into resistance across bloc,' Financial Times. Accessed 4 January 2020 at: https://www.ft.com/ content/62d54b38-d396-11e7-a303-9060cb1e5f44.

Busch, Danny (2018), 'A stronger role for the European Supervisory Authorities in the EU27,' in Danny Busch, Emiliano Avgouleas and Guido Ferrarini (eds), Capital Markets Union in Europe, Oxford: Oxford University Press, 29-54.

Busuioc, E.M. (2016), 'Friend or foe? Inter-agency cooperation, organizational reputation, and turf,' Public Administration, 94 (1), 40-56.

City of London (2016), 'Shaping legislation: UK engagement in EU financial services policy-making.' Accessed 15 November 2019 at: https://www.cityoflondon.gov .uk/business/economic-research-and-information/research-publications/Documents/ research-2016/shaping-EU-legislation-2.pdf.

Deutsche Börse Group (2017), 'Deutsche Börse Group response to the public consultation on the operations of the European Supervisory Authorities.' Accessed 12 September 2019 at: https:/www.deutsche-boerse.com/resource/blob/59518/ 2264e7df68d43a5e3264ebccdb26ba86/data/20170321-response-to-operations-of -the-european-supervisory-authorities.pdf.

Deutsche Bundesbank (2014), 'Deutsche Bundesbank's reply to the European Commission's Green Paper "Building a Capital Markets Union".' Accessed 15 September 2019 at: https://www.bundesbank.de/resource/blob/666796/2c7871a875 $437 \mathrm{fd} 1 \mathrm{a} 8 \mathrm{e} 3422 \mathrm{~d} 04560 \mathrm{cab} / \mathrm{mL} / 2015-05-21$-statement-capital-market-union -answers-data.pdf.

Draghi, M. (2018), 'Risk-reducing and risk-sharing in our Monetary Union,' Speech delivered at the European University Institute, 11 May.

EMIR 2012 (2012), Regulation (EU) No 648/2012 of the European Parliament and of the Council of 4 July 2012 on OTC derivatives, central counterparties and trade repositories text with EEA relevance, OJ L 201, 27 July 2012, pp. 1-59; amended multiple times. Accessed 4 January 2020 at: https://eur-lex.europa.eu/legal-content/ EN/TXT/?uri=CELEX:02012R0648-20190617.

EMIR 2019 (2019), Regulation (EU) 2019/834 of the European Parliament and of the Council of 20 May 2019 amending Regulation (EU) No 648/2012 as regards the clearing obligation, the suspension of the clearing obligation, the reporting requirements, the risk-mitigation techniques for OTC derivative contracts not cleared by a central counterparty, the registration and supervision of trade repositories and 
the requirements for trade repositories, OJ L 141, 28 May 2019, pp. 42-63 and Regulation (EU) 2019 of the European Parliament and of the Council of 23 October 2019 amending Regulation (EU) No 648/2012 as regards the procedures and authorities involved for the authorisation of CCPs and requirements for the recognition of extra-EU CCPs [awaiting publication in the Official Journal].

ESMA (2015), 'Guidelines and recommendations regarding written agreements between members of CCP colleges.' Accessed 15 September 2019 at: https:/www .esma.europa.eu/sites/default/files/library/2015/11/2013-661_report_gr_on_college written_agreement__final_for_publication_20130604.pdf.

ESMA (2019a), 'List of competent authorities designated for the purposes of Regulation (EU) No. 648/2012 on OTC derivatives, central counterparties and trade repositories (EMIR).' Accessed 4 January 2020 at: https://www.esma.europa.eu/sites/default/ files/emir.pdf.

ESMA (2019b), 'Annual Statistical Report on EU Derivatives Markets.' Accessed 20 September 2019 at: https://www.esma.europa.eu/sites/default/files/library/esma50 -165-639_esma-rae_asr-derivatives_2018.pdf.

European Central Bank (2017), Recommendation for a Decision of the European Parliament and of the Council amending Article 22 of the Statute of the European System of Central Banks and of the European Central Bank.

European Central Bank (2019), Withdrawal of the Recommendation for the ECB for a Decision of the European Parliament and the Council amending Article 22 of the Statute of the European System of Central Banks and of the European Central Bank, Letter to Antonio Tajani, President of the European Parliament, 20 March 2019.

European Commission (2017a), Communication on responding to challenges for critical financial market infrastructures and further developing the Capital Markets Union, No. COM/2017/0225.

European Commission (2017b), Proposal for a Regulation of the European Parliament and of the Council amending Regulation (EU) No 1095/2010 establishing a European Supervisory Authority (European Securities and Markets Authority) and amending Regulation (EU) No 648/2012 as regards the procedures and authorities involved for the authorisation of CCPs and requirements for the recognition of third-country CCPs. Procedure 2017/0136/COD. Accessed 4 January 2020 at: https://eur-lex .europa.eu/procedure/EN/2017_136.

European Commission (2017c), Communication on the mid-term review of the Capital Markets Union action plan, No. 292 final.

European Commission (2017d), Proposal for a Regulation of the European Parliament and the Council amending Regulation (EU) No 1095/2010 establishing a European Supervisory Authority (European Securities and Markets Authority) and amending Regulation (EU) No 648/2012 as regards the procedures and authorities involved for the authorisation of CCPs and requirements for the recognition of third-country CCPs, Procedure No. 2017/0136 (COD).

European Commission (2018), Commission Implementing Decision (EU) 2018/2031 of 19 December 2018 determining, for a limited period of time, that the regulatory framework applicable to central counterparties in the United Kingdom of Great Britain and Northern Ireland is equivalent, in accordance with Regulation (EU) No 648/2012 of the European Parliament and of the Council C/2018/9139, OJ L 325, 20 December 2018, pp. 50-52.

FIA (2017), Letter to Vice-President Valdis Dombrovskis, 6 June. 
Financial Times (2011a), 'EU states in clearing houses authorisation push,' 9 May. Accessed 4 January 2020 at: https://www.ft.com/content/15e6b066-7a4a-11e0-bc74 -00144 feabdc 0.

Financial Times (2011b), 'UK gets best of compromise on Emir,' 4 October. Accessed 4 January 2020 at: https://www.ft.com/content/b51054d8-eeaf-11e0-959a -00144 feab49a.

Financial Times (2016), 'François Hollande rules out City's euro clearing role,' 29 June. Accessed 4 January 2020 at: https://www.ft.com/content/e8e0c44a-3d89-11e6 $-9 \mathrm{f} 2 \mathrm{c}-36 \mathrm{~b} 487 \mathrm{ebd} 80 \mathrm{a}$.

Financial Times (2018a), 'Germany's Olaf Scholz suggests euro clearing be moved to Frankfurt.' Accessed 4 January 2020 at: https://www.ft.com/content/d8b0e782-6b1b $-11 \mathrm{e} 8-8 \mathrm{cf3}-0 \mathrm{c} 230 \mathrm{fa} 67 \mathrm{aec}$.

Financial Times (2018b), 'Bank of France governor pushes Paris as post-Brexit clearing hub,' 23 November. Accessed 4 January 2020 at: https:/www.ft.com/content/ 088ad4b0-ef09-11e8-8180-9cf212677a57.

Friedrich, J. and M. Thiemann (2017), 'Capital Markets Union: the need for common laws and common supervision,' Vierteljahrshefte zur Wirtschaftsforschung, 86 (2), 61-75.

Genito, L. (2019), 'Mandatory clearing: the infrastructural authority of central counterparty clearing houses in the OTC derivatives market,' Review of International Political Economy, 26 (5), 938-962.

German Federal Government (2014), 'Green Paper of the European Commission on a Capital Markets Union, German Comments.' Accessed 15 July 2018 at: https://ec .europa.eu/eusurvey/publication/capital-markets-union-2015.

Grossule, E. (2019), 'Risks and benefits of the increasing role of ESMA: a perspective from the OTC derivatives regulation in the Brexit period,' European Business Organization Law Review, 1-22.

House of Lords (2017), 'Supervision of central counterparties,' 22 November. Accessed 4 January 2020 at: https://publications.parliament.uk/pa/cm201719/cmselect/ cmeuleg/301-ii/30123.htm.

House of Lords (2018), 'Brexit: EU supervision of UK-based central counterparties.' Accessed 18 September 209 at: https://publications.parliament.uk/pa/cm201719/ cmselect/cmeuleg/301-xlv/30115.htm.

Howarth, D. and Lucia Quaglia (2018), 'Brexit and the battle for financial services,' Journal of European Public Policy, 25 (8), 1118-1136.

ISDA (2017), Letter to Commissioner Valdis Dombrovskis, 8 June. Accessed 5 September 2019 at: https://www.isda.org/a/i8iDE/isda-final-response-to-ec -communication-8-june-2017.pdf.

James, S. and Lucia Quaglia (2019), 'Brexit and the political economy of euro-denominated clearing,' Review of International Political Economy, 1-23.

Marjosola, H. (2015), 'Missing pieces in the patchwork of EU financial stability regime? The case of central counterparties,' Common Market Law Review, 52 (6), 1491-1527.

Moloney, N. (2017), 'Brexit and EU financial governance: business as usual or institutional change?' European Law Review, 42 (1), 112-128.

Quaglia, L., David Howarth and Moritz Liebe (2016), 'The political economy of European capital markets union,' Journal of Common Market Studies, 54, 185-203.

Reuters (2017), 'France wants right to veto euro clearing in UK after Brexit,' 6 September. Accessed 4 January 2020 at: https://www.reuters.com/article/us-britain -eu-clearing-idUSKCN1BH1EL. 
Smoleńska, A. (2017), 'Connecting and disconnecting critical financial market infrastructures: oversight and regulation of CCPs after Brexit,' in Franklin Allen, Elena Carletti, Joanna Gray and Mitu Gulati (eds), The Changing Geography of Finance and Regulation in Europe, Florence: Florence School of Banking and Finance, 141-151.

UK HM Treasury (2018), Letter to Sir William Cash MP, 21 November. Accessed 4 January 2020 at: http://europeanmemoranda.cabinetoffice.gov.uk/files/2018/11/ EST_to_HOC_EU_Committee_-_EMIR_211118.pdf. 